IRA-International Journal of Education \&

Multidisciplinary Studies

ISSN 2455-2526; Vol.17, Issue 02 (Q2, 2021)

Pg. no. 100-107.

IRA Academico Research

\title{
A Review of Intercultural Language Teaching from the Perspectives of ELT Teaching Material Evaluation and Application
}

\author{
Chenyu Yang (iD) \\ School of Foreign Studies of Yangtze University, China.
}

Type of Work: Peer Reviewed.

DOI: 10.21013/jems.v17.n2.p9

DOI URL: https://dx.doi.org/10.21013/jems.v17.n2.pg

How to cite this paper:
Yang, C. (2021). A Review of Intercultural Language Teaching from the Perspectives of ELT Teaching
Material Evaluation and Application. IRA-International Journal of Education \& Multidisciplinary Studies
(ISSN 2455-2526), 17(2), 100-107. DOI: https://dx.doi.org/10.21013/jems.v17.n2.p9

(C) IRA Academico Research.

(c) EY-No 4.0 International License subject to a proper citation to the publication source of the work.

Disclaimer: The scholarly papers as reviewed and published by IRA Academico Research are the views and opinions of their respective authors and are not the views or opinions of IRA Academico Research. IRA Academico Research disclaims any harm or loss caused due to the published content to any party.

IRA Academico Research is an institutional publisher member of Publishers International Linking Association Inc. (PILA-CrossRef), USA. IRA Academico Research is an institutional signatory to the Budapest Open Access Initiative, Hungary advocating the open access of scientific and scholarly knowledge. IRA Academico Research is a registered content provider under Open Access Initiative Protocol for Metadata Harvesting (OAI-PMH).

The journal is indexed \& included in WorldCat Discovery Service (USA), CrossRef Metadata Search (USA), WorldCat (USA), OCLC (USA), Open J-Gate (India), EZB (Germany) Scilit (Switzerland), Airiti (China), Bielefeld Academic Search Engine (BASE) of Bielefeld University, Germany, PKP Index of Simon Fraser University, Canada. 


\section{ABSTRACT}

Review on the evaluation of English Language Teaching (ELT) materials has been carried out by many researchers. Focusing on the cultural aspect, the review covers the three important participants in a classroom setting - coursebook, instructors and students. The review aims to reveal the evaluation of the culture content on ELT materials, to explore and students' attitude towards source culture and international culture teaching in English as Foreign Language (EFL) class as well summarize some strategies adopted by teachers in their teaching process to give inspirations to current EFL teaching. After analyzing the objects, methods and findings of Several empirical researches in a bottom-up method, this review found: 1) there is an imbalance of cultural representation in ELT textbooks between target culture, home culture and international culture; 2) students show a positive attitude towards home culture and international culture learning in the learning process; 3) teachers notice the importance to cultivate students' awareness of their own culture and culture relativism consciously and take measures accordingly in their class.

Keywords: Intercultural Language Teaching; ELT Teaching Material

\section{Introduction:}

In foreign language contexts, ELT materials assume a considerable amount of responsibility for the structuring of class time, classroom interaction, and language learning (Tsagari \& Sifakis, 2014). Good course books foster English language acquisition (Tomlinson, 2008 cited in Toledo-Sandoval, 2020), mediate learning by offering different opportunities to internalize language learning (Swain et al., 2015 cited in Toledo-Sandoval, 2020), and introduce cultural meanings to the learners (Kramsch, cited in Gray, 2010). Given the important role of ELT coursebooks in foreign language acquisition, a lot of researches have been carried out to content analysis of textbooks to see whether they can meet the demand of instructors. Content analysis "follows a more critical approach, aiming to scrutinize and interpret the information presented in the textbooks" (Toledo-Sandoval F., 2020). Focusing on culture content in ELT material, this review is aimed at providing a general profile of the research in material evaluation and application. The research within this frame is found to fall into three dimensions: 1) evaluation of the cultural content in teaching material from instructors' perspective, 2) evaluation of the cultural content in learning material from students' perspective, and 3) studies to explore teachers adapting strategies in dealing with culture content of their teaching material.

\section{Evaluation of the Culture Content in Teaching Material from Instructors' Perspective}

Researchers categorized culture contents in ELT materials from different angles. Byram (1993) identified eight features of cultural content found in foreign language textbooks as follows: social identity, social interaction, belief and behaviour, social and political institutions, socialization, national history, national geography, and stereotypes and national identity. While Cortazzi and Jin (1999) identify three approaches to culture in ELT textbooks in terms of the nation: the source culture, the target culture, or the international culture (as cited in Zhang \& Ma, 2004; Toledo-Sandoval F., 2020). From the ideological dimension, Risager and Chapelle (2012) introduce two perspectives of cultural representation in language textbooks: The modernist approach which emphasizes offering learners some basic and authoritative knowledge of the target language country and the postmodernist which emphasizes the role of different perspectives in cultural representation. What's more, Simsek (2014) divided culture contents presented in the coursebook in a detailed way as follows: universal topics like friendship, international topics like success stories, language-related topics like good language and local topics like the Turkish War of Independence. 
This section reviewed empirical research of the representation of cultural content in Teaching Material from Instructors' Perspectives. Most of the research adapt a detailed content analysis to analyze the government-approved coursebook (Simsek, 2014; Arslan, 2016; Toledo-Sandoval, 2020; Zhang \& Yu, 2020) and findings show that: 1) there is an imbalance of cultural representation in ELT textbooks between target culture, home culture and international culture; 2) ELT textbooks focus more on U.S or U.K culture and give little inspiration of culture reflection to its readers; 3) even some textbook presents the learns' local culture, there may be some stereotypes, misrepresentations or outdated information;

Arslan(2016) explored the cultural content and frequency of use of elements related to home culture, target culture and international culture in a series of textbooks for $3^{\text {rd }}$ and $4^{\text {th }}$ grade and found there is an imbalance between cultural content, i.e., indigenous culture is less than target culture and cross-cultural content. Similarly, Demirba (2013) selected local coursebooks randomly and investigated the proportion of intercultural, target culture and source culture in the ELT coursebook respectively. He found that the book which had the most intercultural items consisted of mostly local culture and a little intercultural, and other textbooks seemed to include most items related to target culture but least items in the intercultural area and explained the reason for this may result from writers' and students' national identity. In other words, it seems that the balance could not be well established in terms of including international cultural and target cultural items in ELT coursebooks.

Another characteristic is U.S or U.K culture occupies a large proportion of cultural contents of ELT materials for a long time (Wang, 2010; Demirba, 2013; Zhang \& Yu, 2020). For instance, Zhang \& Yu (2020) applied a typical case sampling method to select four sets of college English textbooks, analyzed the text content systemically and founded western culture dominate in ELT materials while Chinese culture is mainly implicitly represented in monotonous types of exercises such as translation and blank-filling items. Furthermore, even textbooks for English major occurs this problem, Wang (2010) conducted an evaluation on cultural content of textbooks for English majors and stated that the thoughts, customs and lifestyles of English-speaking countries occupy a large proportion in coursebook while Chinese culture (students' source culture) a very small proportion.

Although some textbooks include cultures related to learners' own country or other countries, they may present in a relatively one-sided way or lack depth. Simsek (2014) conducted a detailed unit analysis on a representative unit in the government-approved coursebooks, analyzed a gender-biased, stereotypical material in the local coursebook which displays a stereotypical Turkish couple (though being given Anglo-American names), and demonstrated that kind of cultural content may attribute to students' misunderstanding about gender roles in the family. Besides, it is pointed out coursebook only presents local tourist information successfully, but the culture content lacks depth. In this respect, Toledo-Sandoval (2020) analyzed the culture content in a historical approach to see the changes in government-approved textbooks. He applied Byram's framework in the process of culture content analysis, and the analysis reveals that in Chile, local culture content observed in the textbooks are inconsistent, and most of them are "national geography" and "stereotypes and national identity" and fails to represent the various actors of the national society, including minorities which is to say it misrepresents the indigenous learners in textbooks.

In addition to the content-analysis of coursebooks from Instructors' Perspective, the other two factors should be taken into consideration - the learners' evaluation towards coursebooks and instructors' application, which will be illustrated later in this review. 


\section{Evaluation of the Culture Content in Learning Material from Students' Perspective}

Since the Anglophone cultures dominate in ELT materials and EFL class, students are overwhelmed with western culture'. Zhang \& Ma (2004) concerned students' evaluation of the cultural content of ELT materials and surveyed Chinese learners' needs for the cultural context of English teaching materials. Findings show most students prefer textbooks that present more intercultural and local culture than merely target culture and clarify studying English is not equivalent to think totally as English or American people do, nor fully accept their social culture, values and beliefs. Arslan (2016) further illustrate the reason why native culture should be included is that learners can get ready to make reflections about the values, beliefs and traditions of others, and international culture foster empathy towards other cultures and enable them to venture beyond their personal boundaries. What's more, according to Liu\& Fang (2017) and Fang (2015), students showed dissatisfaction towards the single representation of western culture in ELT materials and a positive attitude towards intercultural and source culture learning and said it would be necessary and crucial for them to be exposed to different countries culture and reflect on their own culture when learning English. Therefore, it's necessary to demystify traditional Anglophone cultures and to acknowledge that they should not be perceived as the sole benchmark for the transmission of values and cultures in ELT practice, and to call for an integration of home culture and other cultures into the English language curriculum, material development and pedagogical practice.

\section{Studies to Explore Teachers' Adapting Strategies in Dealing with Culture Content of Their Teaching Material}

Due to the limitation of teaching materials, teachers are responsible to exercise their professional judgement about when and how a material can be adapted for a particular purpose (Maley, 2011). It is suggested that teachers can draw independent pathways to developing and implementing the final product, i.e., the coursebook (Tsagari \& Sifakis, 2014). Although Hu (2011) states Target culture teaching can 'help the students transcend their own culture and see things as the members of the target culture will, and emphasize the inseparability of understanding language and understanding culture through various classroom practices', McKay (2011) point out English, as an international language, 'cannot be linked to any one country or culture; rather it must belong to those who use it. In addition, students call for an integration of source culture, target culture and international culture.

Taking the above factors into consideration, the final section reviewed instructors' adapting strategies in dealing with the cultural content of their teaching material. As Mario \& Elba (2014) proposed teachers adapt Teaching materials to fit students' needs, comply with curricular demands, supplement information, provide extra practice, and so on. For the whole process of language teaching, Maley (2011) summarized 12 coursebooks adapting strategies: expansion, reduction, media transfer, matching, selection/ranking, comparison/contrast, reconstruction, reformulation, interpretation, creating text, analysis and project work and detailed applicable criterion of each. Simsek (2014) used five of them, say addition, modification, omission, reordering, and replacement of culture content to conduct research to increase students' awareness of cross-cultural differences, cultivate the ability to critically question cultural stereotypes and develop a tolerance for cultures other than their own.

From the perspective of the difference between localized materials and international ones, Mario and Elba (2014) identified four categories which include contextualization, linguistic contrast, intercultural reflection and focus on learning. He conducted a survey in Argentine through a follow-up open questionnaire and an interview to explore how teachers use and adapt textbooks, and the most frequent action was connecting coursebooks to the 
real world which the learners live in by adding local culture references, such as familiar personalities, places, facts and folklore. Later, Toledo-Sandoval (2020) adapted these categories to codes teacher's statements about their perception and actual teaching behaviours about localizing ELT materials in his study. Findings reveal that the teachers localize the textbooks mainly by adding local culture references, intercultural reflections and linguistic contrast does not appear to be a common practice among these teachers. However, as Zhang \& Yu (2020) explained it is worth comparing native culture with source culture as well other countries culture. Such comparison can arouse students' intercultural reflection, develop a sense of respect for cultural diversity as well enhance the confidence of their own culture. (Li, 2014; Yin \& Gao, 2018; Li, 2019).

In fact, the strategies generalized by Maley (2011) overlapped with the ones distinguished by Mario and Elba (2014) to some extent, for example, contextualization is similar to expansion because they both refer to adding local culture references. But the later focus more on the cultural teaching process. In sum, it is suggested that teachers can take adapting measures according to the actual teaching situation. Options such as watching movies, reading, on-spot learning, surfing the Internet, and talking with foreigners are favoured by students (Fang, 2011), as well to introduce and compare the local culture with the culture of other countries based on the theme of the text to cultivate intercultural awareness (Xu, 2016).

\section{Concluding Comments and Implications}

The present review has been subject to limitations: the data set was small, although the ELT materials content-analysis covers coursebooks from primary school to university, the evaluation and assessment of ELT textbooks focused on the university. Furthermore, the empirical research was not enough, especially in the student's evaluation and assessment of the ELT materials section. The review suggested that attention should be paid to the feeling of and students who use the materials in an authentic context.

In conclusion, the present review highlights several findings: the culture contents in ELT materials present a tendency of oversimplification, outdated, stereotyped information. Besides, given the role of English as a lingua franca, it calls for a balance and integration of source culture and international culture, and focuses on the learners' own country, enabling them to describe and appreciate their own culture in communication with foreigners (Risager, 2012), and tries to avoid "Chinese cultural aphasia" in English teaching." (Xu, 2016).

Another finding highlighted by the present review is that learners and instructors were not satisfied with the culture content on ELT materials on the whole as the traditional Anglophone cultures dominate in EFL class. Confining the target language to its native setting could be unrealistic and misleading (Alptekin, 1993), learners can find themselves in a totally strange and isolated environment (Iriskulova, 2012). Integrating an intercultural aspect makes learners from other cultures feel intimate with what is written (Arslan, 2016). Inevitably, it calls for a balance and integration between source, target and international culture so as to increase students' awareness towards their own cultures, to share their own culture in the international arena of communication, as well to show respect to the culture of the world's countries. Due to the limitation of teaching materials and students' needs, the teacher was tasked with a heavy-duty as Risager (2012) also states "textbooks provided learners with their first authoritative glimpses of target culture" and language teaching is guided and structured by published textbooks sometimes with supplemented material selected by teachers from other materials or internet in the practical teaching process. Adding local references, intercultural reflections and linguistic contrast are good ways to cultivate culture relativism and self-confidence in native culture. 
IRA-International Journal of Education \& Multidisciplinary Studies

In exploring the characteristics of culture content presented in ELT coursebooks, student's evaluation towards it as well the action taken by instructors, the present study found some problems: (1) empirical research related to students' perception and assessment on culture content in ELT textbooks are relatively small; (2) instructors only add materials like local reference but neglect the importance of cultivating intercultural reflection. Despite the limitations, given the importance of the ELT coursebook in EFL learning, the author hopes that the coursebook author and instructors can get inspiration. Enriching cultural content and improving the textbook culture system to realize the goal of cultural inheritance and cross-cultural communication of English teaching.

\begin{tabular}{|c|c|c|c|c|}
\hline AUTHOR & YEARS & RESEARCH TOPIC & METHODS & FINDINGS \\
\hline $\begin{array}{c}\text { Simsek, Meliha } \\
\text { R. }\end{array}$ & 2014 & $\begin{array}{l}\text { Adapting a Turkish } \\
\text { Middle } \\
\text { Textbook to Develop } \\
\text { Cultural Awareness }\end{array}$ & $\begin{array}{l}\text { Qualitative: } \\
\text { detailed unit } \\
\text { analysis }\end{array}$ & $\begin{array}{l}\text { (1) coursebooks fall short of } \\
\text { expectations for their focusing on } \\
\text { language items and local context } \\
\text { instead of the international } \\
\text { situation. } \\
\text { (2) the presence of local culture } \\
\text { was limited to local tourist } \\
\text { information and varied stereotypes }\end{array}$ \\
\hline Arslan, Sezen. & 2016 & $\begin{array}{l}\text { An Analysis of Two } \\
\text { Turkish EFL Books in } \\
\text { Terms of Cultural } \\
\text { Aspects }\end{array}$ & $\begin{array}{l}\text { Mixed-methods. } \\
\text { Qualitative: a } \\
\text { descriptive content } \\
\text { analysis. } \\
\text { Quantitative: } \\
\text { inventory and } \\
\text { project frequency } \\
\text { analysis. }\end{array}$ & $\begin{array}{l}\text { (1) the dialogues may not seem } \\
\text { realistic because the interlocutors } \\
\text { from different countries (whatever } \\
\text { their nationalities are) speak the } \\
\text { same accent-target language } \\
\text { accent; (2) there is an imbalance } \\
\text { between cultural content, i.e., } \\
\text { indigenous culture is less than } \\
\text { target culture and cross-cultural } \\
\text { content. }\end{array}$ \\
\hline $\begin{array}{c}\text { Toledo-Sandoval } \\
\text { F. }\end{array}$ & 2020 & $\begin{array}{l}\text { Local culture and } \\
\text { locally produced ELT } \\
\text { textbooks: How do } \\
\text { teachers bridge the } \\
\text { gap? }\end{array}$ & $\begin{array}{l}\text { Mixed-methods. } \\
\text { Qualitative: } \\
\text { descriptive content } \\
\text { analysis, } \\
\text { Quantitative: } \\
\text { Online } \\
\text { questionnaire }\end{array}$ & $\begin{array}{l}\text { local culture content observed in } \\
\text { the textbooks are inconsistent, and } \\
\text { most of them are "national } \\
\text { geography" and "stereotypes and } \\
\text { national identity" and fails to } \\
\text { represent the various actors of the } \\
\text { national society, including } \\
\text { minorities. }\end{array}$ \\
\hline $\begin{array}{c}\text { Zhang Hong \& } \\
\text { Yu Rui }\end{array}$ & 2020 & $\begin{array}{l}\text { Representation of } \\
\text { Chinese culture in } \\
\text { China's College } \\
\text { English textbooks }\end{array}$ & $\begin{array}{l}\text { Typical case } \\
\text { sampling method }\end{array}$ & $\begin{array}{l}\text { (1) Chinese culture represented in } \\
\mathrm{CE} \text { textbooks mainly comprises } \\
\text { traditional culture and } \\
\text { contemporary culture; (2) Chinese } \\
\text { culture is mainly implicitly } \\
\text { represented in monotonous types } \\
\text { of exercises such as translation } \\
\text { and blank-filling items. In view of } \\
\text { the existing problems, the issues }\end{array}$ \\
\hline
\end{tabular}




\begin{tabular}{|c|c|c|c|c|}
\hline AUTHOR & YEARS & $\begin{array}{l}\text { RESEARCH } \\
\text { TOPIC }\end{array}$ & METHODS & ADAPTING STRATEGIES \\
\hline Maley, A. & 2011 & $\begin{array}{l}\text { Squaring the } \\
\text { circle: } \\
\text { Reconciling } \\
\text { materials as a } \\
\text { constraint with } \\
\text { materials as } \\
\text { empowerment. }\end{array}$ & & $\begin{array}{l}\text { Maley summarized } 12 \text { adapting strategies: } \\
\text { expansion, reduction, media transfer, matching, } \\
\text { selection/ranking, } \\
\text { reconstruction, reformulation, interpretation, } \\
\text { creating text, analysis and project work. }\end{array}$ \\
\hline $\begin{array}{l}\text { Simsek, Meliha } \\
\text { R. }\end{array}$ & 2014 & $\begin{array}{l}\text { Adapting a } \\
\text { Turkish middle } \\
\text { school } \\
\text { textbook to } \\
\text { develop } \\
\text { cultural } \\
\text { awareness }\end{array}$ & $\begin{array}{l}\text { Descriptive } \\
\text { content } \\
\text { analysis }\end{array}$ & $\begin{array}{l}\text { Apply the adaptation of Maley's } 12 \text { strategies: } \\
\text { addition, modification, omission, reordering, and } \\
\text { replacement in an authentic teaching setting. } \\
\text { The originally sexist and unstimulating materials } \\
\text { have been reconstructed and exploited to resist } \\
\text { stereotyping and to develop students' cultural } \\
\text { awareness and tolerance. }\end{array}$ \\
\hline $\begin{array}{l}\text { Mario L ó } \\
\text { pez-Barrios, } \\
\text { Debat E V D. }\end{array}$ & 2014 & $\begin{array}{l}\text { global vs. } \\
\text { Local: Does It } \\
\text { Matter? }\end{array}$ & $\begin{array}{l}\text { a survey, } \\
\text { a follow-up } \\
\text { open } \\
\text { questionnaire } \\
\text { and an } \\
\text { interview. }\end{array}$ & $\begin{array}{l}\text { State all teachers adapted coursebooks and } \\
\text { identified four main categories: contextualization, } \\
\text { linguistic contrast, intercultural reflection and } \\
\text { focus on learning }\end{array}$ \\
\hline $\begin{array}{l}\text { Toledo-Sandoval } \\
\text { F. }\end{array}$ & 2020 & $\begin{array}{l}\text { Local culture } \\
\text { and locally } \\
\text { produced ELT } \\
\text { textbooks: } \\
\text { How do } \\
\text { teachers bridge } \\
\text { the gap? }\end{array}$ & $\begin{array}{l}\text { descriptive } \\
\text { analysis, } \\
\text { Online } \\
\text { questionnaire, }\end{array}$ & $\begin{array}{l}\text { Localize the textbooks mainly by adding local } \\
\text { references, and intercultural reflection and } \\
\text { linguistic contrast do not appear to be a common } \\
\text { practice among these teachers. }\end{array}$ \\
\hline Alptekin C. & 2006 & $\begin{array}{l}\text { Cultural } \\
\text { familiarity in } \\
\text { inferential and } \\
\text { literal } \\
\text { comprehension } \\
\text { in L2 reading }\end{array}$ & $\begin{array}{l}\text { Quantitative } \\
\text { (the } \\
\text { experimental } \\
\text { group Vs. the } \\
\text { control } \\
\text { group) }\end{array}$ & $\begin{array}{l}\text { Nativization of a short story from the target } \\
\text { language culture facilitates L2 readers' inferential } \\
\text { comprehension significantly, yet does not affect } \\
\text { their literal understanding. }\end{array}$ \\
\hline
\end{tabular}

\section{References:}

[1]. Arslan, Sezen. An Analysis of Two Turkish EFL Books in Terms of Cultural Aspects [J]. Procedia - Social 
and Behavioral Sciences, 2016, 232:217-225.

[2]. Alptekin, C. (1993). Target-Language Culture in EFL Materials. ELT Journal, 47(2), 136-143. London: Oxford University Press.

[3]. Alptekin C. Cultural familiarity in inferential and literal comprehension in L2 reading [J]. System, 2006, 34(4):494-508.

[4]. Byram, M. (1993). Language and culture learning: The need for integration. In M. Byram (Ed.), Germany, its representation in the textbooks for teaching German in Great Britain (p. 3e16). Frankfurt am Main: Diesterweg.

[5]. Demirbas M N. Investigating Intercultural Elements in English Coursebooks [J]. Journal of Kirsehir Education Faculty, 2013.

[6]. Fang F G. International Cultures in the Framework of World Englishes: What should EFL Teachers Do [J]. Journal of Asia Tefl, 2011, 8(1):111-137.

[7]. Liu J, Fang F G. Perceptions, awareness and perceived effects of home culture on intercultural communication: Perspectives of university students in China [J]. System, 2017, 67:25-37.

[8]. Mario López-Barrios, Debat E V D . Global vs. Local: Does It Matter? [J]. 2014.

[9]. Maley, A. (2011). Squaring the circle: Reconciling materials as constraint with materials as empowerment. In B. Tomlinson (Ed.), Materials development in language teaching (pp. 379-402). Cambridge: Cambridge University Press.

[10]. Risager K, Chapelle C A. Culture in Textbook Analysis and Evaluation [M]. The Encyclopedia of Applied Linguistics. Blackwell Publishing Ltd, 2012.

[11]. Simsek, Meliha R. Adapting a Turkish Middle School Textbook to Develop Cultural Awareness [J]. Procedia - Social and Behavioral Sciences, 2014, 152:199-204.

[12]. Toledo-Sandoval F. Local culture and locally produced ELT textbooks: How do teachers bridge the gap? [J]. System, 2020.

[13]. Tsagari D, Sifakis N C. EFL course book evaluation in Greek primary schools: Views from teachers and authors [J]. System, 2014, 45:211-226.

[14]. Lu Jiawei. Chinese foreign language education based on cultural openness [J]. China Adult Education, 2015(05):131-134.

[15]. Li Guiling. The introduction and strategies of local culture in college English teaching [J]. Educational Theory and Practice, 2014, 34(18): 57-59.

[16]. Li Ying. An analysis of the input of local culture in English education in local colleges and universities in ethnic regions $[\mathrm{J}]$. Theories of Education and Teaching

[17]. Wang Chunhua. Evaluation of cultural content and cultural teaching of English major textbooks [J]. Journal of Capital University of Economics and Business, 2010, 12(06): 122-123.

[18]. Xu Ruomeng. On the "Cultural Aphasia" and Inheritance of the Publishing of English Textbooks in my country [J]. Publishing Wide Angle, 2016, No. 259(01):83-84.

[19]. Yin Rong, Gao Xuyang. Interpretation of junior high school English textbook text from the perspective of effective teaching [J]. Teaching and Management, 2018(04): 61-63.

[20]. Zhang Hong, Yu Rui. Research on the Presentation of Chinese Culture in College English Textbooks [J]. Frontiers of Foreign Language Education Research, 2020, 3(03): 42-48+91.

[21]. Zhang Bei, Ma Lan. Investigation and Research on the Cultural Content of College English Textbooks [J]. Foreign Language World, 2004(04):60-66. 